\title{
MACIEJ SZCZEPANIAK \\ Patrzenie obrazu. Obrazowanie jako strategia komunikacyjna w przepowiadaniu
}

Jednym z najważniejszych wyzwań dla teologa (praktycznego), m.in. dla kaznodziei, jest dotarcie do odbiorcy. Nie chcemy, by słuchano nas jak muzyki w tle, jak dźwięku tykającego zegara. Można odnieść wrażenie, że zwłaszcza dziś stoimy przed słuchaczem zanurzonym $\mathrm{w}$ szerokim nurcie wielorakich przekazów, które skutecznie zagłuszają przepowiadanie kerygmatyczne. Nawiązując do rysunku zamieszczonego we włoskich środkach społecznego przekazu jako ilustracji jednej z audiencji papieskich ${ }^{1}$, mamy prawo pytać, co zrobić, by wpłynąć na przemianę słuchacza: by chciał on usłyszeć wypowiadane do niego słowa, zdjąć słuchawki i uklęknąć przed Bogiem.

\section{Znaczenie posługiwania się obrazami w przepowiadaniu słowa Bożego}

Zapewne jedną z odpowiedzi daje realizacja postulatu obrazowego przepowiadania. Propozycja nie jest nowa. Wynika ona wprost z doświadczenia ewangelizacyjnego Kościoła, który na wzór Jezusa Chrystusa, chętnie korzystającego $\mathrm{z}$ porównań i przypowieści, niejednokrotnie posługiwał się $\mathrm{w}$ przepowiadaniu językiem przemawiającym do ludzkiej wyobraźni. Chrystus dat się poznać jako doskonaty "Glosiciel». Przez wcielenie upodobnit się do tych, którzy mieli Go kiedyś stuchać (...) i przyjąt sposób mówienia i myślenia wtaściwy krajowi i jego

Maciej S Z C ZEP A N I A K, ks. dr hab., Zakład Liturgiki i Homiletyki, Wydział Teologiczny Uniwersytetu im. Adama Mickiewicza w Poznaniu, e-mail: ms@amu.edu.pl

${ }^{1} \mathrm{http}$ //angelusdominicartoonit.blogspot.it/ [dostęp: 11.10.2015]. 
sytuacji ${ }^{2}$. W przeciwieństwie do starotestamentalnych maszal czy znanych w świecie greckim alegorii Jezus - jak pisze W. Pikor - czerpał obrazy dla swoich przypowieści z codziennego życia ludzi: miejsc, które stanowia środowisko ich życia i pracy (pole, winnica, gospodarstwo, dom itd.), wspólnot, które tworza (rodzina, społeczeństwo, naród, obcy) i sytuacji, które moga być udziałem człowieka $w$ relacji do innych (przebaczenie, nadużywanie władzy, pycha, zazdrość, dtug itd. $)^{3}$. W swoim przepowiadaniu Jezus kreślił przed słuchaczami obraz Boga daleki od abstrakcji i teoretyzowania, przybliżał im Boga, który przychodzi do ludzi, jest im bliski, działa na sposób im podobny, jak choćby za pośrednictwem metafory ojca, króla, pasterza, właściciela winnicy, spóźniającego się oblubień$\mathrm{ca}^{4}$. Zamiarem Jezusa było zobrazowanie nauczania, aby słuchacz łatwiej mógł zrozumieć to, co On chciał przekazać ${ }^{5}$.

Ten sposób przepowiadania treści kerygmatycznych wpisał się w długą historię kaznodziejstwa ${ }^{6}$. Wystarczy przywołać przykład Ojców Kościoła, którzy często opierali kazania na obrazach egzystencjalnych; niekiedy samo wydarzenie ewangelijne stawało się dla nich ilustracją przeżyć słuchaczy. Dobrym przykładem jest tu interpretacja opowiadania o burzy na morzu, które w ustach wybitnych kaznodziejów czasów patrystycznych było obrazem prześladowań dotykających łodzi Kościoła (który płynie przez świat miotany falami prób), niepowodzeń i pokus doświadczanych przez chrześcijan (życie człowieka to podróż przez jezioro, nie brak na nim burz i wiatru, wiatrem może być zniewaga, falą gniew), czy też alegorią Męki Chrystusa (łódka to krzyż, na który wstąpił Chrystus dla naszego odkupienia) ${ }^{7}$.

Dyrektorium homiletyczne $(2014)^{8}$, powołując się na adhortację apostolską Franciszka o głoszeniu Ewangelii w dzisiejszym świecie - Evangelii gaudium, przypomniało współczesnym kaznodziejom znaczenie posługiwania się obrazami w przepowiadaniu słowa Bożego: Jedna z rzeczy najważniejszych jest nauczenie sie postugiwania $w$ przepowiadaniu obrazami, czyli przemawiania obrazami. Czasem używa się przyktadów, aby uczynić bardziej zrozumiałym coś, co chce się wyjaśnić, ale te przykłady często odnosza się tylko do rozumowania; natomiast

\footnotetext{
${ }^{2}$ Papieska Komisja ds. Środków Społecznego Przekazu: Instrukcja duszpasterska o środkach społecznego przekazu Communio et progressio. $1971 \mathrm{nr} 11$.

${ }^{3}$ W. P i k o r: Przypowieści Jezusa. Narracyjny klucz lektury. Kielce 2011 s. 7.

${ }^{4}$ Tamże; por. J. Tre l a : Przypowieści Jezusa a starotestamentalne i rabinackie meszalim. Lublin 1997 s. 51-61; A. J. H u 1 t g r e n : Le parabole di Gesù. Brescia 2004 s. 27-30.

${ }^{5}$ Por. R. M e y n e t: Język przypowieści biblijnych. Kraków 2005 s. 57.

${ }^{6}$ Por. K. P a n u ś : Historia kaznodziejstwa. Kraków 2007 s. 88.

${ }^{7}$ Por. np. Hilary z Poitiers: Comm. in Mt VI,6. PL 9,953; Comm. in Mt VII,7-8. PL 9,956; A u gu st y n : Enarr. in Ps 54,24. PL 36,66; Enarr. in Ps 25(2),3-4. PL 36,189n; C h r omacjusz z Akwile i: Sermo 37,1. SC 164 (1971) s. 202.

${ }^{8}$ Kongregacja ds. Kultu Bożego i Dyscypliny Sakramentów: Dyrektorium homiletyczne. thum. pl. Poznań 2015 s. 32.
} 
obrazy pomagaja $w$ docenieniu i przyjęciu przesłania, które chcemy przekazać. Atrakcyjny obraz sprawia, że przestanie jest odczuwane jako coś swojskiego", bliskiego, możliwego, powiąanego z naszym życiem. Trafny obraz może doprowadzić do zasmakowania w przesłaniu, które pragniemy przekazać, budzi pragnienie i motywuje wole $\mathrm{ku}$ Ewangelii ${ }^{10}$.

Użyte w tekście sformułowanie „przemawianie obrazami” wyznacza kierunek naszej refleksji nad obrazowaniem ${ }^{11} \mathrm{w}$ przepowiadaniu. Chodzi nam o przekazywanie myśli i uczuć za pomocą wyrażanych słowem obrazów, o budowanie w świadomości słuchacza obrazów jako wyobrażenia rzeczywistości realnej, choć nie do końca realistycznej, bo przecież często treści zbawcze nie naśladują rzeczywistości i nie odwołują się do obserwowanych wyglądów rzeczy i zjawisk - głosimy, jak zostało napisane, to, czego ani oko nie widziato, ani ucho nie styszało, ani serce człowieka nie zdołało pojać (1 Kor 2,9).

Potrzeba obrazowania jest tym bardziej nagląca, że żyjemy w kulturze obrazu. Już alfabet fonetyczny, zamieniając dźwięk w przestrzeń (W. Ong), stworzył swego rodzaju ,zerwanie oka z uchem” i sprawił, że widzenie stało się priorytetem w organizacji myśli ludzkiej; ludzie szybko zamienili ucho na oko (H. M. McLuhan). Muzykolog Ł. Kamieński pisał: już od pierwszych zórz historii z uchem rywalizuje zwycięsko jako drugi pośrednik kultury duchowej oko, odtad stały już prymas wśród zmystów ludzkich, któremu i ucho placu nie dotrzymuje $^{12}$. Zwracał uwagę na to, że wszystkie języki nowożytne rozbudowały wyrazy przenośne wzięte $z$ wrażenia optycznego, a nie słuchowego: widzieć, mieć na oku, rzucać się w oczy, widocznie, oczywiście, jak choćby w stwierdze-

\footnotetext{
${ }^{9}$ Pojawiające się w polskim tłumaczeniu adhortacji określenie „coś swojskiego” (po włosku familiare, po angielsku familiar) byłoby chyba lepiej oddać jako: coś rodzimego, dobrze znanego, zażyłego, familijnego, rodzinnego; swojski kojarzy się chyba bardziej z kiełbasą czy zapachem niż z przesłaniem; por. Stownik języka polskiego. Red. M. S z y m c z a k. T. 3. Warszawa 1990 s. 376.

${ }^{10} \mathrm{Fr}$ a n c i s z e k: Adhortacja apostolska Evangelii gaudium o głoszeniu Ewangelii w dzisiejszym świecie. 2013 n. 157. Pojawiające się w polskim przekładzie stwierdzenie ,przemawiać obrazami” jest polską kalką semantyczną włoskiego tekstu adhortacji (także hiszpańskiego, francuskiego czy portugalskiego) parlare con immagini; jedynie w angielskim tłumaczeniu adhortacji użyto sformułowania appeal to imagery, „odwoływać się do wyobraźni”. W języku polskim należałoby raczej powiedzieć „mówić obrazowo”, „przedstawiać obrazowo”.

${ }^{11}$ Obrazowanie: sposób przekazywania $w$ dziele artystycznym myśli, uczuć lub fragmentów rzeczywistości za pomoca odpowiednich środków; http://sjp.pwn.pl/sjp/obrazowanie;2491883.html [dostęp: 1.9.2015]; Obrazowanie, sposób budowania obrazu literackiego jako wyobrażenia świata przedstawionego, który powstaje w świadomości czytelnika. Z uwagi na elementy charakterystyczne dla twórcy, kierunku lub epoki wyróżnia się: obrazowanie realistyczne - naśladujące przedstawiana rzeczywistość, odwotujące się do obserwowanych wyglądów rzeczy, zjawisk, osób; obrazowanie deformujace - zniekształcajace rzeczywistość, stąd elementy świata realnego ulegaja udziwnieniu; obrazowanie fantastyczne - tworzace obrazy bez ich odpowiedników w realnym świecie; http://portalwiedzy.onet.pl/93284,,,obrazowanie,haslo.html [dostęp: 1.9.2015].

${ }^{12}$ Ł. Kamieński: $O$ radjokulturze uwag kilka. „Tydzień Radjowy”. R. 1: 1927 nr 2 s. 2.
} 
niu „widocznie muzyka ta wyobraża to i to" czy też „widzisz go, jaki mądry”. Kamieński nazywał to zjawisko „przesiąknięciem światopoglądem optycznym”.

Skoro przepowiadanie to słowne głoszenie orędzia, powinniśmy zastanawiać się, co zrobić, by w czasach cywilizacji obrazu, a więc w sytuacji, gdy oku ,ucho placu nie dotrzymuje", nie osłabła moc słów. Paweł VI przekonywał, że nawet jeśli dzisiaj ludzie sa już przesyceni mowami, bardzo często znudzeni stuchaniem, a co gorsza, nieczuli na stowa, wobec zjawiska rzekomej nieskuteczności i nieużyteczności cywilizacji słowa w czasach cywilizacji obrazu, trzeba do głoszenia Ewangelii stosować świeże środki, jakimi dysponuje ta cywilizacja ${ }^{13}$.

Niniejszy artykuł podejmuje zagadnienie wpływu obrazu na mediację zbawczą Kościoła na gruncie teologii homiletycznej i teologii środków społecznego przekazu. Chcielibyśmy zaproponować oparcie się na „obrazach”, które potraktujemy jako swego rodzaju awatary, czyli reprezentacje, ikony, obrazki, tak dobrze funkcjonujące dziś w świecie elektronicznej komunikacji, wprowadzające nas w świat przepowiadania i teologii praktycznej.

\section{Przykłady obrazowania}

Słowo „obraz” jest pojęciem bardzo szerokim. Może oznaczać materialny przedmiot (obraz Velasqueza) i wyimaginowany mentalny byt (wspomnienia z dzieciństwa), może być nim werbalny motyw, metafora, słowo przypominające jakieś zjawisko. Mówienie o obrazowaniu w przepowiadaniu znajduje swoje uzasadnienie w przekonaniu, iż działalność ewangelizacyjna musi być rozeznana na poziomie treści i formy przekazu. Treści podane są wprawdzie za pomocą ludzkich słów, ale forma wpływa także na treść.

\section{Obraz pierwszy: okna}

Amerykański historyk sztuki W.J.T. Mitchell uważa, że okna sa być może jednym z najważniejszych wynalazków w historii kultury wizualnej, otwierającym architekturę na nowe relacje wnętrza i zewnętrza, przez analogię przekształcajacym wyobrażenie ludzkiego ciała $w$ odniesieniu do wewnętrznych $i$ zewnętrznych przestrzeni, czyniac z oczu okna duszy, z uszu werandy, a z ust perlowe wrota ${ }^{14}$. Okna pozwalają zrozumieć ważną funkcję obrazowania: to miejsce otwarcia, spotkania. Dobrze wyraża tę myśl stosowane w języku nowych technologii słowo interface. Graficznym interfejsem użytkownika nazywa się choćby system operacyjny Windows - „okna” - produkowany przez firmę Microsoft. Korzystając z systemu otwieramy różne „okna”, które pozwalają nam osiągnąć zamierzone

\footnotetext{
${ }^{13}$ Por. P a w e $\nmid$ V I: Adhortacja apostolska Evangelii nuntiandi o ewangelizacji w świecie współczesnym. $1975 \mathrm{nr} 42$.

${ }^{14}$ W.J.T. M i t c h e 11: Czego chcq obrazy. Pragnienia przedstawień, życie i miłości obrazów. Warszawa 2015 s. 243.
} 
rezultaty. Interface to nic innego jak „twarz pomiędzy”, pole, płaszczyzna wspólna dla dwóch podmiotów, miejsce spotkania ${ }^{15}$ : obraz to interface dla mówcy i słuchacza.

Mowa teologa staje się oknem, płaszczyzną porozumienia. Przekaz słowny, pewna zakodowana treść, przywołuje istniejące „,W głowach” obrazy ${ }^{16}$. Obraz, porównanie, metafora, przypominane wydarzenia sprawiają, że słuchacze mogą „zaglądać" - jak pisał Z. Pilch - do królestwa prawdy: zadaniem kaznodziei jest otwierać stuchaczom jak najwięcej okien $w$ mowie ${ }^{17}$. Dlatego też kaznodzieja powinien rozwijać własną wyobraźnię poprzez odpowiednią lekturę, zainteresowanie malarstwem, muzyką, filmem.

Wybitny angielski poeta George Herbert w wierszu pt. Okna zwraca uwagę na jeszcze jeden istotny aspekt kaznodziejskiej posługi. Słowo homilisty może pełnić funkcję wspólnej płaszczyzny spotkania, jeśli jest on otwarty na laskę Boga:

$$
\begin{gathered}
\text { Jak może człowiek wieczne słowo Twoje głosić, } \\
\text { On, co jak szkło jest kruchy, chwiejny, płaski? } \\
\text { A przecież w Twej świątyni dajesz mu się wznosić } \\
\text { Tam, gdzie go chwały przenikają blaski: } \\
\text { Oknem go czyni potęga Twej łaski }{ }^{18} \text {. }
\end{gathered}
$$

\section{Obraz drugi: waza}

Jednym z mechanizmów percepcyjnych dotyczących obrazów jest rozróżnienie figury od tła. Jego ilustracją może być rysunek wazy opublikowany w 1915 roku przez duńskiego psychologa Edgara Rubina. Spoglądając na rysunek, nasz umysł musi podjąć decyzję, które elementy zyskają status wyróżniającej się figury, a które będą stanowić tło; w zależności od decyzji widzimy wazę lub też dwie zwrócone ku sobie twarze. Ten efekt psychologiczny wykorzystywał często w swoich grafikach holenderski artysta Maurits Cornelis Escher.

Język grecki na określenie obrazu używał słów eidolón (to co jest widziane), eikón (to, co odtwarza, uobecnia rzeczywistość) i ágalma (obraz święty, tajemniczy i magiczny, który angażował bóstwo i oddającego mu cześć). Wszystkie te znaczenia nie pozostają bez wpływu na nasze rozumienie obrazowania i jego ważne funkcje:

${ }^{15}$ Interface. W: A.S. H o r n b y: Oxford Advanced Learner's Dictionary of Current English. Oxford 1980 s. 445. Słowniki etymologiczne datują pojawienie się tego słowa na koniec XIX wieku, por. http://www.etymonline.com/index.php?term=interface [dostęp: 1.9.2015].

${ }^{16}$ Por. J. P l e s z c z yń ski: Dwa atomy komunikacji. W: Rozmowy o komunikacji. Red. G. H a b r a j s k a . Łask 2010 s. 28.

${ }^{17}$ Z. P i 1 c h: Wykład zasad kościelnej wymowy. Poznań 1950 s. 150.

${ }^{18}$ G. H e r b e r t: Okna. W: G. H e r b e r t: Wiersze wybrane. Tłum. S. B a r a ń c z a k. Kraków 1989 s. 47. 
- do istoty obrazu należy to, że daje się zobaczyć, bycie widzianym należy do jego istoty; obraz nie jest czymś samoistnym, powstaje wtedy, gdy zostaje zobaczony;

- widzenie obrazu pozwala na poznanie nowej rzeczywistości;

- jest w nim pewna doza tajemniczości, która angażuje osoby, w naszym przypadku twórcę przekazu i słuchacza.

Widać zatem, że zagadnienie mówienia obrazowego można ująć w kategoriach performatywów, stwarzających pewną rzeczywistość; obraz patrzy, chce, przemawia. By zaistnieć, obraz słowny nie tylko musi zostać przekazany (transmisja), ale też zrozumiany. Ostatecznie liczy się jednak jego oddziaływanie na odbiorcę.

Berlińska szkoła radiotechniczna w latach 20. ubiegłego wieku posługiwała się metaforą lejka: stacja radiowa to nie lejek, przez który wypłynie wszystko tak, jak się wleje. Dlatego twórca przekazu homilijnego powinien zdawać sobie sprawę, że obrazy mają swoje „życie”, są zdolne wytwarzać nowe skojarzenia. Podmiot przepowiadający poprzez ukazywanie jakiejś rzeczywistości za pomocą obrazu prowadzi słuchacza w nowy świat, który często jest im obu nieznany. Kiedy spoglądamy na tekst biblijny i zaczynamy o nim mówić, mamy tekst, ale nie mamy treści - to my ostatecznie, kaznodzieja i słuchacz, wydobywamy tę treść, odkrywamy ją w Duchu Świętym.

\section{Obraz trzeci: emotikon}

Emotikony (ang. emoticon = emotion icon) to ideogramy złożone ze znaków tekstowych, które nauczyliśmy się stosować w komunikacji elektronicznej (e-mail, blog, tweet, SMS) dla przekazania uczuć i podkreślenia tonu wypowiedzi. W opublikowanym w „Social Neuroscience” artykule na temat „emotikonów w mózgu", australijscy naukowcy wykazali, że widok znaków :-) uaktywniał u badanych dokładnie te same części mózgu co wizerunek prawdziwej uśmiechniętej twarzy (pewien określony obszar mózgu człowieka uaktywnia się wyłącznie przy identyfikacji twarzy). Badanie neurologicznych podstaw nowych sposobów komunikacji pokazało, że nauczyliśmy się, że dwukropek, myślnik i nawias to twarz, a mózg, rejestrując ten ciąg symboli, używa obszarów odpowiedzialnych za rejestrowanie twarzy, a nie tych identyfikujących inne znaki graficzne ${ }^{19}$. Znak odwrócony (-: nie wywoływał żadnych reakcji obszarów odpowiedzialnych za identyfikację twarzy: te same znaki w odwrotnej kolejności dla naszego mózgu pozostają tylko zwykłym obrazem.

Można przez analogię powiedzieć, że obrazowanie w kaznodziejstwie jest po to, by budzić pewne określone obszary rozumowania. Proces ten jest wielo-

${ }^{19}$ O. Churches, M. Nicholls, M. Thiessen, M. Kohler, H. Keage: Emoticons in mind: An event-related potential study. „Social Neuroscience”. T. 9: $2014 \mathrm{nr} 2$ s. 201. 
stopniowy. Zaczyna się od kontekstu wypowiedzi. Zanim słuchacz zobaczy wypowiadane przez nas słowo oczyma wyobraźni, przemawia do niego wizualność świata zewnętrznego. To ona staje się ważnym kontekstem przepowiadania: najpierw przestrzeń świątyni i jej architektura, sprawowana liturgia, obecność innych słuchaczy, zachowania kaznodziei. Podmiot przepowiadający maluje w wyobraźni słuchaczy obrazy najpierw własną postawą: gesty są pierwotnym sposobem obrazowania myśli, jak najbardziej ikonicznym (obrazowym) i motywacyjno-wyobrażeniowym $^{20}$, a ręce $\mathrm{w}$ komunikacji niosq wyobrażenia idei i myśli, których semantyczny wymiar nie mieści się $w$ toku werbalizacji ${ }^{21}$. Szczególne znaczenie przypisać można spojrzeniu kaznodziei - obrazowanie zaczyna się od „daru oczu”, a przemawianie z oczyma zamkniętymi albo utkwionymi w pulpicie, w kartce papieru czy w odległym punkcie kościoła osłabia przekaz ${ }^{22}$. Słowo obrazujące treści zbawcze wypływa $\mathrm{z}$ bogatego kontekstu komunikowania ${ }^{23}$.

W. Kosiński przekonywał kaznodziejów, że obrazowość raczej nie powinna polegać na posługiwaniu się rekwizytami w kościele (podobnie jak w szkole, kiedy np. uczniom pokazuje się roślinę, motyla czy kawałek metalu), ponieważ kościelne rekwizyty (krucyfiks czy trumna) dają ograniczone możliwości. Nawet jeśli dziś rozmaite środki audiowizualne znacząco poszerzają możliwości rekwizytorium, wydaje się, że mogą jedynie pełnić funkcję pomocniczą. Postulowana przez Kosińskiego poglądowość umysłowa polegała zarówno na przejrzystym układzie kazania, języku zrozumiałym i przystępnym, umiejętnej dykcji, jak i na stosowaniu właściwych figur retorycznych i wyjaśnienia ${ }^{24}$.

Obrazowanie w mowie zaczyna się już od pierwszych słów kaznodziei. Inny obraz wspólnoty, do której przemawia, maluje mówca, rozpoczynając homilię słowami „najmilsi”, inny - gdy mówi „plemię żmijowe”; inaczej odbiera się kaznodzieję, który potrafi nawiązać w adresie wypowiedzi do tematu mowy (,dzieci ochrzczonego narodu”), inaczej - gdy większość obecnych w kościele słuchaczy zostaje zauważona jedynie w ogólnym ,siostry i bracia” na końcu pozdrowienia. Niekiedy pozdrowienie uczestników wydarzenia liturgicznego może dawać wyraz emocjonalnego nastawienia mówcy do grupy odbiorców, jak

${ }^{20} \mathrm{~J}$. A n t a s: Co mówia ręce. Wprowadzenie do komunikacji niewerbalnej. W: Retoryka dziś. Teoria i praktyka. Red. R. P r z y b y 1 s k a, W. P r z y c z y n a. Kraków 2001 s. 439.

${ }^{21}$ Tamże s. 456.

${ }^{22}$ Por. G. S i w e k: Blaski i cienie wspótczesnego przepowiadania. Kraków 2007 s. 148-149.

${ }^{23}$ Por. R. G a r p i e l: Obrazowość w kaznodziejskim komunikowaniu perswazyjnym. W: Sztuka perswazji. Socjologiczne, psychologiczne i lingwistyczne aspekty komunikowania perswazyjnego. Red. R. G a r p i e l, K. L e s z c z y ń s k a. Kraków 2004 s. 106.

${ }^{24}$ W. K o s i ń s k i: Kazanie obrazowe. „Przegląd Homiletyczny”. R. 3: 1925 s. 178-180. 
w przypadku introdukcji Jana Pawła II, zwracającego się do wiernych na krakowskim rynku „Krakowianie i goście” ${ }^{25}$.

Także sposób posługiwania się słowem, dykcja, szybsza lub wolniejsza wymowa pewnych głosek, oddech, chwila milczenia, zawieszenie głosu, mogą stawać się ważnym elementem obrazowania. Brzmienie słowa wpływa na treść przekazu. Wystarczy przypomnieć zastosowanie przez Jana Pawła II biblijnego, zaczerpniętego z przeżywanej przez wiernych liturgii, obrazu zstąpienia Ducha ożywiającego ziemię: retoryczne repetitio i gradatio (trzykrotnie wypowiedziane „wołam”), zawieszenie głosu, cicho wypowiedziane słowa „tej ziemi”, nie tylko powtarzały obraz biblijny, ale na nowo go tworzyły ${ }^{26}$.

Do najważniejszych figur retorycznych ułatwiających obrazowanie należy metafora, dzięki której filozofowie, poeci, mistycy, ale także homiliści wyrażają to, co w języku nie ma jeszcze gotowych formuł. Metafory i porównania odnoszą się do świata wzrokowej wyobraźni, pozwalają zobaczyć więcej niż precyzyjne krótkie stwierdzenia. Zamiast: „młodzież jest dziś bardzo zajęta”, można namalować obraz słowem: Młodzi maja tyle na głowie chociażby włosów / Poza tym szkołe miłość i konflikt pokoleń (J. Pasierb, Stare kobiety w kościele) ${ }^{27}$. Zamiast: nie powinno się plotkować, można, jak Franciszek, przekonywać: plotkowanie to terroryzm, to jak rzucić bombę by zniszczyć innych, a potem zaczać uciekać by ocalić siebie samego $^{28}$. Nic więc dziwnego, że w teologii homiletycznej stawia się dziś postulat doskonalenia warsztatu kaznodziejskiego poprzez czytanie poezji, bo ona wyraża to, co niewyrażalne ${ }^{29}$. W ten sposób uczymy się także unikania stwierdzeń czy obrazów wytartych, w złym guście, zbyt modnych czy kolokwialnych, by mogły godnie wyrazić przeżycia religijne, typu: „modlić się to marudzić Panu Bogu, ciągnąć Go za rękaw"’30.

25 Jan Paweł II: Homilia podczas mszy beatyfikacyjnej Anieli Salawy. Kraków 13.8.1991.

${ }^{26}$ I wołam, ja, syn polskiej ziemi, a zarazem ja: Jan Pawet II papiez, wołam z całej głębi tego tysiaclecia, wołam $w$ przeddzień święta Zesłania, wołam wraz z wami wszystkimi: Niech zstapi Duch Twój! Niech zstapi Duch Twój! I odnowi oblicze ziemi. Tej Ziemi! J a n P a w e 1 I I: Homilia na placu Zwycięstwa. Warszawa 2.6.1979.

${ }^{27} \mathrm{~J} . \mathrm{P}$ a s i e r b: Wiersze wybrane. Warszawa 1988 s. 165.

${ }^{28}$ Sparlare degli altri è terrorismo, è come buttare una bomba per distruggere le persone e poi darsela a gambe e mettere in salvo se stessi, F r a n c is ze k: Homilia w Domu św. Marty. Rzym 4.9.2015.

${ }^{29}$ Por. H. S ł a w i ń s k i: Rola wyobraźni w przepowiadaniu słowa Bożego. „Studia Włocławskie". T. 8: 2005 s. 235.

${ }^{30} \mathrm{~J}$. Miodek wylicza wiele podobnych chybionych obrazów i kolokwialnych metafor skierowanych np. do dzieci: „bądźmy i my kumplami Pana Boga”, „Pan Bóg może się wkurzyć”, „Jan Chrzciciel trafił w dziesiątkę”, „Maryja - to taka stacja przekaźnikowa między nami a Chrystusem”, „Bóg nie jest piłką, którą można kopnąć”; por. J. M i o d e k: Co słyszy językoznawca we wspótczesnych polskich kazaniach?. W: Fenomen kazania. Red. W. P r z y c z y n a. Kraków 1994 s. $159-161$. 
Głoszone przez kaznodzieję orędzie - jak zauważa Z. Grzegorski - domaga się zobrazowania problemu, a więc elementu i pogladowego, i przeżyciowego, a $i$ zaintrygowania, zaskoczenia... I tu jest możliwe sięgnięcie $i$ do literatury po funkcjonalny, najczęściej skrócony - no cóż, trzeba się z tym zgodzić... - cytat, relację. Zrelacjonowanie sytuacji, przed jaka stanat człowiek $-w$ przekazie filmowym, w narracji literackiej-i jak ja rozwiazat... ${ }^{31}$. Ważne jest przy tym skoncentrowanie uwagi na słuchaczu, by zobrazowane słowo nie stanowiło odpowiedzi na pytania, których nikt nie stawia. To właśnie pytanie rodzi dialog, zmusza do myślenia, pozwala postawić problem. Świadczy o tym choćby popularność rubryk czy audycji odpowiadających na pytania czytelników czy słuchaczy (np. audycja w 1 programie Polskiego Radia „Wszystko, co chciałbyś wiedzieć i nie boisz się zapytać") $)^{32}$.

Przemawianie do wyobraźni może opierać się również na tzw. ikoniczności obrazowej, czyli np. wyrazach dźwiękonaśladowczych (przerażeni tupotem bydląt i syczeniem gadów zamierali ze strachu, Mdr 17,9); ikoniczności diagramatycznej, np. poprzez reduplikację wyrazów na tworzenie liczby mnogiej („on idzie i idzie”, „łatwo łatwo”); ikoniczności semantycznej, w której połączenia wyrazowe wywołują obraz (,,mroczne myśli”, „,łłodka zemsta”). Obrazowanie to także wsparcie argumentacji poprzez opowiadanie, narrację, z łatwością odbieraną przez ludzką świadomość, obfitującą w analogie, które niemal pozwalają dotknąć innej rzeczywistości. Niekiedy warto też dokonać akomodacji biblijnych porównań - jak choćby wyjaśniając przypowieść o perle (Mt 13,45-46) obrazem znalezionego lekarstwa na raka.

Funkcjonalność tak postrzeganego obrazu powinna brać pod uwagę charakter współczesnego przekazu, zwłaszcza medialnego. Pięć klasycznych „in” $\mathrm{z}$ teorii dziennikarstwa brzmi: interest - zainteresować, inform - informować, instruct - uczyć, involve (your audience) wciągać kogoś, inspire - inspirować. Powinno zależeć nam na tym, byśmy zainteresowali słuchacza, umieli zawrzeć w obrazie element informacyjny i dydaktyczny, wprowadzili go w pewien nowy świat i zainspirowali do nowego życia. Nie można też zapominać o pięciu ,„” na określenie języka komunikatu w dobie Internetu: short - krótki; searchable zawierający słowa klucze; social - budujący relacje społeczne; simple - prosty, nieskomplikowany, surprising - zaskakujący. Obrazowanie pomaga też autorowi

${ }^{31}$ Z. G r z e g o r s k i: Monolog czy dialog? Między pięknem a skutecznościa - ujęcie kontekstualne. „Poznańskie Studia Teologiczne”. T. 14: 2003 s. 127.

${ }^{32}$ W 2006 r. w kontekście obrad Synodu Archidiecezji Poznańskiej środki społecznego przekazu obiegła informacja: Wierni będa mogli zamawiać kazania (por. „Dziennik”, 4.10.2006). Mówiono o potrzebie dawania słuchaczom odpowiedzi na nurtujące ich pytania - sugerowano, że będzie je można zadawać podczas spotkań zespołów liturgicznych, indywidualnie, e-mailem, na stronie internetowej. Intuicja poznańskiego synodu wydaje się godna zauważenia, zwłaszcza w kontekście kulturowym współczesnych środków przekazu. 
wypowiedzi, wspiera jego pamięć - łatwiej zapamiętać przygotowaną homilię, jeśli wspiera się ona na rdzeniu obrazowym.

\section{Obraz czwarty: gramofon}

G. Siwek porównywał przepowiadanie z reportażem, powołując się na przemyślenia Melchiora Wańkowicza ${ }^{33}$. W książce Prosto od krowy pisarz bronił reportaż przed postulatem neutralności. Obrazowanie może sprawić, że przepowiadanie nie będzie neutralną egzegezą i akademickim wykładem. Podmiot przepowiadający już przez sam fakt poszukiwania własnego przeżywania świata staje się emocjonalnie zaangażowany, sam daje się ponieść obrazowanej prawdzie o świecie, by „zarazić”, zaszczepić ją w innych. Wańkowicz mówi tu o chtonności, czyli wrażliwości na odbierane podniety, o zdolności patrzenia $\mathrm{z}$ różnych stron, o otworzeniu wszystkich klap chłonnych, o szukaniu słowa smacznego, kolorowego, pachnącego, kojącego ${ }^{34}$. Jeślibym pojechat do ludożerców, to postarałabym dołożyć wszelkich wysitków, aby zrozumieć apetyt na ludz$k a$ wątróbkę $e^{35}$. Takie było przepowiadanie apostolskie: Dla stabych stałem się jak staby, by pozyskać stabych. Statem się wszystkim dla wszystkich, żeby w ogóle ocalić przynajmniej niektórych (1 Kor 9,22).

W. Noskowski w artykule o audycjach radiowych pisał: Odczyt radjowy może stać się czemś niewypowiedzianie nudnem. (...) Niech Was nie uwodzi sugestia mikrofonu. Wyobrażacie sobie za nim tysiace uszu, które równocześnie was stuchaja. To omyłka. Nie myślcie, że mówicie przed audytorium. Mówcie do jednego człowieka. (...) żywy czlowiek do żywego człowieka, a nie żywy i stremowany gramofon do mikrofonu... (...) Nawet wyktadać można zajmująco, albo nasennie, można wpleść na dziesięć formul chemicznych jedna anegdotę i formuly nia uratowac $c^{36}$. Recepta Noskowskiego na nudę funkcjonuje także w teologii i w duszpasterstwie: powinniśmy mówić do człowieka, żywy człowiek do żywego człowieka, a nie gramofon do mikrofonu... trzeba ratować formuły wiary. Na pewno pomagają $w$ tym obrazy.

W 2005 roku trzy osoby wymyśliły portal społecznościowy, który przełamał dotychczasowe spojrzenie na film. You Tube (,ty nadajesz”, „ty emitujesz”) umożliwia bezpłatne umieszczanie i oglądanie filmów w Internecie. W założeniu chodziło o to, żeby „wyrazić siebie” (broadcast yourself, slogan do 2012 r.), a więc opowiedzieć coś o sobie za pomocą obrazu. W przepowiadaniu słowa Bożego mamy do czynienia z porównywalnym zadaniem. Podobnie jak autor Apokalipsy, musimy nauczyć się myśleć symbolicznie i rozumować obrazami. Księga, która zrodziła się w kontekście liturgii i dla liturgii, uczy nas wykorzy-

\footnotetext{
${ }^{33}$ Por. G. S i w e k: Blaski i cienie wspótczesnego przepowiadania. Kraków 2007 s. 96.

${ }^{34}$ M. W a ń k o w i c z: Prosto od krowy. Warszawa 1965 s. 57.

${ }^{35}$ Tamże s. 29.

${ }^{36}$ W. N o s k o w s k i: Pogawędki, nie „,prelekcje”!., ,Tydzień Radjowy”. R. 1: 1927 nr 2 s. 2.
} 
stania myślenia obrazami do przepowiadania: liczy się wydarzenie, przeskoki myślowe nie zaburzają w niczym logiki narracji, obraz nie trąci sztucznością. Obrazy zapamiętujemy dużo łatwiej niż trudne do przełknięcia wywody myślowe. Teolog „też nadaje”.

\section{Obraz piąty: znikanie}

W opowiadaniu o rozmowie Jezusa z uczniami w Emaus pojawia się dwukrotnie słowo dianoigo, otwierać: Wtedy oczy im się otworzyly i poznali Go, lecz On znikną im z oczu. I mówili nawzajem do siebie: Czy serce nie pałało w nas, kiedy rozmawiał $z$ nami $w$ drodze i Pisma nam wyjaśniat? (Łk 24,31-32), a właściwie „otwierał”. W tekście Łukasza zachodzi wyraźna analogia pomiędzy otwieraniem oczu na widok obrazu - znaku łamania chleba, a otwieraniem Pisma, tekstu, słowa ${ }^{37}$. Otwarcie oczu sprawia, że obraz może zniknąć, spełnił już swe zadanie (On zniknął im z oczu). Ważne jest to, co się zdarzyło.

Ostatecznie zatem obrazowanie jest po to, by patrzący na nadawcę i odbiorcę obraz mógł zniknąć. Teologowi powinno zależeć na tym, by w przekazie treści zbawczych obrazy stanowiły jedynie pomost, który pozwoli słuchaczowi odkryć kerygmat. Wtedy zdejmie z uszu słuchawki i uklęknie przed Bogiem.

\section{Bibliografia}

Antas J.: Co mówiq ręce. Wprowadzenie do komunikacji niewerbalnej. W: Retoryka dziś. Teoria i praktyka. Pod redakcją R. Przybylskiej, W. Przyczyny. Kraków 2001 s. 437-60. Draguła A.: Eucharystia zmediatyzowana. Teologiczno-pastoralna interpretacja transmisji Mszy Świętej w radiu i telewizji. Zielona Góra 2009.

Franciszek: Adhortacja apostolska Evangelii gaudium o głoszeniu Ewangelii w dzisiejszym świecie. 2013.

Garpiel R.: Obrazowość w kaznodziejskim komunikowaniu perswazyjnym. W: Sztuka perswazji. Socjologiczne, psychologiczne i lingwistyczne aspekty komunikowania perswazyjnego. Pod redakcją R. Garpiela, K. Leszczyńskiej. Kraków 2004 s. 101-113.

Grzegorski Z.: Monolog czy dialog? Między pięknem a skutecznościq - ujęcie kontekstualne. „Poznańskie Studia Teologiczne”. T. 14: 2003 s. 121-133.

Kongregacja ds. Kultu Bożego i Dyscypliny Sakramentów: Dyrektorium homiletyczne. Tłum. pl. Poznań 2015.

Kosiński W.: Kazanie obrazowe. „Przegląd Homiletyczny”. R. 3: 1925 s. 175-182, 241248.

Miodek J.: Co słyszy językoznawca we wspótczesnych polskich kazaniach?. W: Fenomen kazania. Pod redakcją W. Przyczyny. Kraków 1994 s. 157-161.

Mitchell W.J.T.: Czego chca obrazy. Pragnienia przedstawień, życie i mitości obrazów. Warszawa 2015.

${ }^{37}$ Por. A. D ra guła: Eucharystia zmediatyzowana. Teologiczno-pastoralna interpretacja transmisji Mszy Świętej w radiu i telewizji. Zielona Góra 2009 s. 74-75. 
Panuś K.: Historia kaznodziejstwa. Kraków 2007.

Papieska Komisja ds. Środków Społecznego Przekazu: Instrukcja duszpasterska o środkach społecznego przekazu Communio et progressio. 1971.

Paweł VI: Adhortacja apostolska Evangelii nuntiandi o ewangelizacji w świecie współczesnym. 1975.

Pikor W.: Przypowieści Jezusa. Narracyjny klucz lektury. Kielce 2011.

Pilch Z.: Wykład zasad kościelnej wymowy. Poznań 1950.Pleszczyński J.: Dwa atomy komunikacji. W: Rozmowy o komunikacji. Pod redakcją G. Habrajskiej. Łask 2010 s. 1735 .

Siwek G.: Blaski i cienie wspótczesnego przepowiadania. Kraków 2007.

Sławiński H.: Rola wyobraźni w przepowiadaniu słowa Bożego. „Studia Włocławskie”. T. 8: 2005 s. 224-237.

\section{ABSTRACT \\ The look of an image. The use of imagery as communication strategy in preaching}

The Homiletic Directory (2014), referring to the apostolic exhortation of Pope Francis Evangelii gaudium „On the Proclamation of the Gospel in Today's World”, reminds contemporary preachers of the significance of using images in proclaiming the word of God: One of the most important things is to learn how to use images in preaching, how to appeal to imagery. The need of depiction is all the more pressing as we live in a visual culture, and modern man is sated by talk; he is obviously often tired of listening and, what is worse, impervious to words (Pope Paul VI). The article tackles the issue of the impact of images on the salvific mediation of the Church on the ground of homiletic theology and the theology of mass media. The author bases his argument on several avatars which function very successfully in today's world of electronic communication. $\mathrm{He}$ describes the process of appealing to imagination on the example of the image of a window, vase, emoticon, gramophone and vanishing.

The preacher paints pictures in the imagination of the listeners first of all by means of his own attitude: gestures, hand movement, look. Also articulation, a faster or slower pronunciation of sounds, as well as moments of silence can become important elements of imagery. The world of visual imagination is particularly compatible with metaphors and comparisons, analogies and suitable narration. The functionality of an image perceived in this way should take into account the character of the contemporary message, especially the media message.

Key words: homiletic theology, use of imagery, preaching, mass media.

Słowa kluczowe: teologia homiletyczna, obrazowanie, kaznodziejstwo, mass media. 